\title{
道德认知、道德情绪与亲社会行为的关系：来自元分析 的证据
}

尚思源 ${ }^{1,2}$, 苏彦捷 ${ }^{2 *}$

1. 杭州师范大学心理科学研究院, 浙江省认知障碍评估技术研究重点实验室, 杭州 311121 ;

2. 北京大学心理与认知科学学院, 行为与心理健康北京市重点实验室, 北京 100871

*联系人, E-mail: yjsu@pku.edu.cn

2019-10-29 收稿, 2019-12-10 修回, 2019-12-13 接受, 2019-12-13 网络版发表

国家自然科学基金(31872782，31571134)资助

摘要 有关道德认知、道德情绪与亲社会行为的关系一直备受研究者的关注, 但现有的研究结果并不一致, 尤其 是道德认知和道德情绪对亲社会行为影响的异同及其在个体发展进程中的发展变化，仍需要进一步探究. 基于39 个效应值9960名被试(道德认知)和 29 个效应值6946名被试(道德情绪)的元分析, 发现道德认知和道德情绪均与亲 社会行为存在中等程度的相关，但年龄组的调节作用均未达显著水平。进一步比较道德认知和道德情绪对亲社会 行为的影响, 结果仅在青少年阶段发现, 道德情绪与亲社会行为的关系更为密切. 这些结果确认了道德认知和道德 情绪对亲社会行为的影响, 提示了在不同发展阶段中道德认知和道德情绪作用的差异性, 有助于更好地理解个体 的道德发展.

关键词道德认知, 道德情绪, 亲社会行为, 元分析

道德能力对于社会和个人、家庭、同伴关系都有 着重要的作用 ${ }^{[1]}$, 因而得到广泛的关注. 道德(morality) 是“一种社会意识形式，指以善恶评价的方式调整人与 人、人与社会之间相互关系的标准、原则和规范的总 和, 也指那些与此相应的行为和活动”, ${ }^{[2,3]}$. 而在心理学 研究中, 道德能力包含了能够评价行为的对错、其中 涉及的情感反应, 以及做出道德的行为这 3 个方面 ${ }^{[4]}$. 对儿童和成人的大量研究发现, 道德能力的认知成分 和情绪成分能够对个体的社会互动和社会行为产生一 定的影响 ${ }^{[5,6]}$. 其中, 亲社会行为(prosocial behavior)可以 看作是道德发展中一个重要的维度. 它指的是“旨在使 他人收益的行为" ${ }^{[7]}$, 亲社会行为反映了指向他人的正 性情绪、态度和行为 ${ }^{[8]}$, 对个体的自尊、学业成就、 幸福感和积极社会互动等能够起到积极的作用 ${ }^{[9]}$.
道德心理学中有关理性与情感的争论早已有之. 自Kohlberg建立道德认知发展模型以来, 道德认知的重 要性得到了广泛的关注, 其中不少研究探讨了道德认 知与亲社会行为的关系 ${ }^{[10,11]}$. 例如, Eisenberg和Shell ${ }^{[12]}$ 的研究中, 实验者向儿童讲述一个道德两难故事, 故事 中一个小朋友要去朋友家参加生日聚会, 在途中遇到 了另一个小朋友摔倒在路旁, 那么这个小朋友是会停 下来帮助这个摔倒的小朋友，让自己错过生日会和生 日蛋糕; 还是会直接去生日会, 而无视这个摔倒的小朋 友呢? 研究结果发现, 与Kohlberg的理论一致, 道德认 知发展更好的儿童, 更可能放弃蛋糕和生日会, 认为应 该去帮助摔倒的小朋友. 此外的一些研究, 在个体发展 的不同阶段中探讨了道德认知和亲社会行为的关系, 结果在各个年龄段的被试中均有研究发现，道德认知 
发展更成熟的个体, 具有更亲社会的行为表现 ${ }^{[11,13]}$; 但 也有研究发现了不一致的结果 ${ }^{[14,15]}$.

有研究者认为, 这些研究过分强调了认知的发展, 低估了情绪成分对行为造成的影响 ${ }^{[16,17]}$. 例如, Gilligan认为对他人的关爱和共情等情感反应也同样能够 影响个体的道德判断和社会行为, 尤其是女性 ${ }^{[17,18]}$. Nunner-Winkler和Sodian ${ }^{[19]}$ 的研究也发现, 4 5岁左右 的儿童会去推搡在秋千上玩要的小朋友, 然后自己去 荡秋千. 尽管年幼儿童能够理解违反规则之类的行为 是不道德的, 他们会因为自己玩到了秋千而感到高兴, 即不能够做出正确的道德情绪判断和归因，这被称为 “快乐的损人者(happy victimizer)”现象. 有研究者认为, 在学龄前阶段“快乐的损人者”现象的发现表明，对道 德情绪的理解需要个体将道德规则内化, 进而作用于 对自身行为的调整中, 即能够在一定程度上构成亲社 会行为的动机, 对亲社会行为的影响也可能更为显 著 ${ }^{[5,20]}$. 尤其是近年来, 研究者更为关注和强调道德情 绪对行为的重要作用 ${ }^{[5,21,22]}$, 但有关道德情绪与亲社会 行为的研究也未得到一致性的结果 ${ }^{[23,24]}$.

可见, 尽管已有不少的研究探讨, 但道德认知、道 德情绪与亲社会行为的关系仍需要进一步的明晰, 尤 其是道德认知和道德情绪对于亲社会行为作用的异同. 在目前关于道德理解和亲社会行为关系的研究中, 直 接比较道德认知和道德情绪对亲社会行为影响异同的 工作非常有限, 仅有的几项研究中结果也存在较大的 差异. 例如, Miller等人 ${ }^{[21]}$ 的研究发现, 学龄前儿童他 人指向的道德推理和与同情相关的情绪反应均能够激 发同伴帮助行为; 而Gummerum等人 ${ }^{[25]}$ 的研究则发现, 学龄前儿童在独裁者游戏中的分配数量与其道德情绪 有关, 而与道德判断无关. Ongley等人 ${ }^{[26]}$ 在学龄前和学 龄儿童的研究中发现, 儿童的捐赠行为与其道德推理 能力相关, 而与内疚等道德情绪无显著相关. Malti等 人 $^{[14]}$ 的研究也发现, 教师评价的儿童亲社会行为与儿 童对于违规行为是否应该受到惩罚的评价有关，且只 与违规行为后的道德无关的情绪有关. 在青少年的相 关研究中, Arsenio等人 ${ }^{[27]}$ 与Krettenauer和Eichler ${ }^{[28]}$ 的 研究关注了道德能力与反社会行为的关系, 结果发现 青少年的攻击或违规行为与道德情绪和道德认知都有 密切关系. 这些研究还不能一致地说明道德认知与道 德情绪对亲社会行为影响的程度或强弱, 且在被试群 体、行为类型等方面均存在较大的差异, 不能够进行 直接的比较和解释.
由此, 本研究拟通过元分析的探讨并比较道德认 知与道德情绪对亲社会行为的影响, 这能够在一定程 度上帮助我们解释道德认知和道德情绪与亲社会行为 关系. 此外, 考虑到道德认知和道德情绪随年龄的发展 成熟可能影响其与亲社会行为的关系，元分析中将涉 及被试的年龄阶段纳人作为关注的调节变量.

\section{1 研究方法}

\section{1 文献搜索}

综述1970年1月 2019年8月期间发表的，有关道德 认知、道德情绪与亲社会行为关系的实证研究, 涵盖 学龄前儿童、学龄儿童、青少年和成年在内的不同发 展阶段群体. 研究使用(“道德认知”或“道德推理”或“道 德判断”或“道德情绪”或“情绪归因”)和(“道德行为”或 “亲社会行为”或“行为”)作为关键词组, 在CNKI数据库 和中国优秀硕士学位论文全文数据库以及中国博士学 位论文全文数据库中, 进行中文文献搜索; 使用 (moral reasoning, moral cognition, moral judgment, moral evaluation, moral emotion, emotion attribution)和(prosocial behavior, behavior, action)为关键词组, 在PsycARTICLES，PsycINFO以及ProQuest博硕士论文全文数据 库中, 进行英文文献搜索. 同时参考互联网谷歌学术 (google scholar)中搜索的结果, 从一些重要的文献综述 中补充相关的文献 ${ }^{[20,29]}$, 并根据文献纳人标准进行 篮选.

\section{2 文献纳入标准}

文献纳人标准包括: (1) 包含道德认知和/或道德情 绪与亲社会行为关系的实证研究, 理论、综述性研究 和元分析的数据结果并未包含在其中; (2) 被试年龄在 3 岁以上, 学龄前儿童、学龄儿童、青少年和成人群体, 仅包含典型发展群体; (3) 研究报告了道德认知和/或道 德情绪与亲社会行为关系的相关效应值, 或者可以从 已报告的数据中计算相应的效应值. 文献篮选具体流 程见图S1.

\section{3 文献编码及效应值提取}

为了考察可能的调节变量对道德认知和道德情绪 与亲社会行为关系的作用, 我们对每个研究进行了特 征编码和效应值的提取. 编码的调节变量包括文献信 息(发表年份+作者)、被试群体年龄(学龄前儿童、学 
龄儿童、青少年或成人), 以及数据发表与否(已发表或 未发表), 编码者一致性系数 $\kappa$ 在0.87 1.00之间. 初步分 析发现, 被试群体性别、亲社会行为的测量方式和亲 社会行为的类型对元分析的结果均不存在调节作用, 故在结果分析中, 主要关注了年龄群体的调节作用.

为了更好地分析调节变量对道德认知和道德情绪 与亲社会行为的关系, 在提取效应值的过程中, 我们尽 可能选择详尽的、独立样本的结果. 针对研究中的效 应值, 我们进行了如下处理.

首先, 当前元分析中涉及的研究中, 有 4 个研究(涉 及 6 个效应值)并未直接报告相关系数. 其中 3 个研究(涉 及 4 个效应值)仅报告了回归方程的 $\beta$ 值 ${ }^{[25,30,31]}$. 参考 Malti等人 ${ }^{[20]}$ 在其元分析中的处理方法, 对 $\beta$ 值进行了 转换, 如果 $\beta \geqslant 0$, 则 $r=\beta+0.05$, 否则 $r=\beta$. 其中 1 个 研究(涉及 2 个效应值)仅报告了 2 个群体的均值、标准 差和被试量 ${ }^{[32]}$, 我们使用了Ellis编写的在线效应值计 算工具 ${ }^{[33]}$, 将其效果大小计算为相应的 $r$ 值.

其次, 在使用相关考察道德认知和/或道德情绪与 亲社会行为关系时, 部分研究同时报告了控制了年 龄、性别、一般认知能力等相关因素的偏相关结果, 当前元分析中我们选择纳人偏相关的结果. 在数据预 处理的过程中, 通过元分析的调节变量分析, 并未发现 加人控制变量与否对研究结果的影响, 故在正式的数 据分析中并未将该调节变量纳人考量.

最后, 部分研究中报告了多种道德情绪与亲社会 行为的关系. 元分析中并未对报告的所有数据进行整 合, 而是选择了其中较具代表性的道德情绪(内疚). 元 分析中研究涉及的道德认知、道德情绪和亲社会行为 种类的相关编码具体见表 S1.

在此基础上, 本研究使用了R(3.6.1)软件Metafor程 序包 ${ }^{[34]}$ 进行元分析. 参考前人的研究基础, 我们对研究 间异质性进行了分析, 在研究间异质的情况下, 报告随 机效应模型的结果; 而在研究间同质的情况下, 报告固 定效应模型的结果 ${ }^{[35]}$. 我们还使用漏斗图(funnel plot) 和Rosenthal's Fail-safe $N$ 统计, 并在分析时纳人了数据 是否已发表这调节变量, 以考察元分析结果是否存在 发表偏差.

\section{2 结果}

根据以上编码和效应值提取标准及方法, 通过两 个元分析分别探讨道德认知、道德情绪与亲社会行为 的关系，两个元分析中分别包括39个效应值、9960名
被试(道德认知)和 29 个效应值、6946名被试(道德情 绪). 两个元分析中均涉及丰富的被试年龄群体, 其中未 发表的数据分别占 $15 \%$ 和 $14 \%$.

道德认知和道德情绪与亲社会行为关系的元分析 结果发现(图1), 研究间存在异质性, $Q_{(38)}=160.05$, $P<0.001, I^{2}=79.14$ (道德认知) 和 $Q_{(28)}=131.84, P<0.001$, $I^{2}=79.41$ (道德情绪). 随机效应模型的结果显示, 道德认 知 $(Z=9.28, P<0.001)$ 和道德情绪 $(Z=8.43, P<0.001)$ 与亲 社会行为之间的相关显著, 两者均与亲社会行为具有 中等程度的相关 $r=0.22$ (道德认知)和 $r=0.27$ (道德情绪).

研究间存在显著的异质性, 提示我们可能存在调 节变量影响二者之间的相关关系, 我们将调节变量的 结果总结在表1中. 结果发现, 道德认知和道德情绪与 亲社会行为的关系在研究间保持相对的稳定, 被试年 龄组对道德认知/道德情绪与亲社会行为关系的影响未 达显著水平.

为探讨在与亲社会行为的关系中道德认知和道德 情绪影响的异同, 我们进一步将两个元分析整合起来, 通过交互作用分析考察各个年龄组中道德认知和道德 情绪二者与亲社会行为的关系是否存在差异. 结果发 现, 整体上道德认知和道德情绪二者与亲社会行为的 关系没有显著差异, $Q_{(1)}=1.97, P=0.160$; 其与年龄组的 交互作业也未见显著(图2), $Q_{(7)}=11.95, P=0.102$. 进一步 分年龄组的比较结果发现, 仅在青少年群体中, 道德情 绪与亲社会行为的相关 $(r=0.33)$ 边缘显著地高于道德 认知 $(r=0.19), Q_{(1)}=3.23, P=0.072$.

最后, 针对发表偏差的分析结果漏斗图见图3. Rosenthal's Fail-safe $N=4414$ (道德认知)和4921(道德情绪), 这两个均值大于 $5 K+10$ 的判断标准. 研究是否发表这一 调节变量的分析结果也表明, 已发表与未发表研究结 果之间均不存在显著差异, $Q_{(1)}=0.90, P=0.343$ (道德认 知)和 $Q_{(1)}=0.22, P=0.640$ (道德情绪). 故可以认为在这两 个元分析中存在发表偏差的可能性较小.

\section{3 讨论}

通过对道德认知、道德情绪与亲社会行为关系的 相关研究进行梳理, 比较道德认知、道德情绪与亲社 会行为关系的差异, 及其随年龄的发展变化. 基于39个 效应值9960名被试(道德认知)和29个效应值6946名被 试(道德情绪)的元分析发现, 道德认知、道德情绪与亲 社会行为存在中等程度的相关 $(r=0.22$ 和 $r=0.27)$, 但并 未见已编码的调节变量(年龄)对道德能力与亲社会行 
(a)

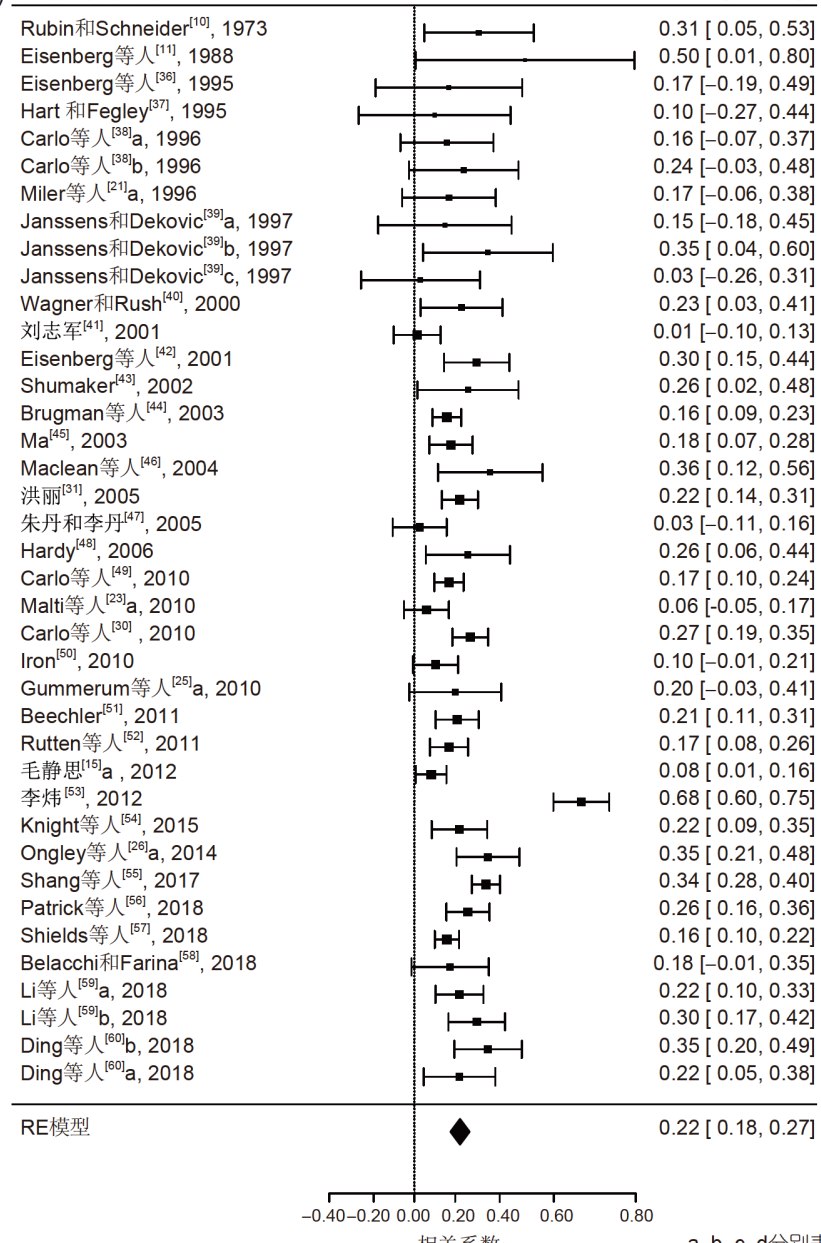

(b)

\begin{tabular}{|c|c|c|}
\hline 作者及发表年份 & & {$[95 \% \mathrm{Cl}]$} \\
\hline Garner $^{[61]}, 1996$ & & $0.07[-0.25,0.37]$ \\
\hline Miler等人 ${ }^{[21]} \mathrm{b}, 1996$ & $\mapsto$ & $0.13[-0.10,0.35]$ \\
\hline DeHaan和Hanford ${ }^{[62]}, 1997$ & & $0.39[0.14,0.60]$ \\
\hline Koening等人 ${ }^{[1]}, 2004$ & & $0.22[0.00,0.42]$ \\
\hline Malti等人 ${ }^{[63]}$ a, 2007 & $\longrightarrow$ & $0.19[-0.05,0.41]$ \\
\hline Malti等人 ${ }^{[63]} \mathrm{b}, 2007$ & $\square$ & $0.23[0.01,0.43]$ \\
\hline Malti等人 ${ }^{[14]} a, 2009$ & $1=1$ & $0.06[-0.09,0.21]$ \\
\hline Malti等人 ${ }^{[14]}$ b, 2009 & 벙 & $0.47[0.43,0.51]$ \\
\hline Johnston ${ }^{[64]}, 2009$ & $\mapsto$ & $0.15[0.01,0.28]$ \\
\hline Malti等人 ${ }^{[23]} b, 2010$ & $1=-1$ & $0.06[-0.05,0.17]$ \\
\hline Gummerum等人 ${ }^{[25]}$ b, 2010 & $\longmapsto$ & $0.55[0.37,0.69]$ \\
\hline de Hooge 等人 ${ }^{[32]}$ a, 2011 & & $0.36[0.07,0.60]$ \\
\hline de Hooge等人 ${ }^{[32]}$ b, 2011 & $\longmapsto$ & $0.36[0.21,0.50]$ \\
\hline O'Mara等人 ${ }^{[65]}, 2011$ & $\longrightarrow$ & $0.18[-0.14,0.47]$ \\
\hline 毛静思 ${ }^{[15]} \mathrm{b}, 2012$ & $H=1$ & $0.36[0.29,0.42]$ \\
\hline Ongley等人 ${ }^{[26]} \mathrm{b}, 2014$ & $\rightarrow-1$ & $0.14[-0.02,0.29]$ \\
\hline van de Vyver和Abrams ${ }^{[6]}, 2015$ & & $0.23[0.05,0.40]$ \\
\hline Ketelaa等人 ${ }^{[67]} \mathrm{b}, 2015$ & $\mapsto$ & $0.03[-0.12,0.17]$ \\
\hline Ketelaa等人 ${ }^{[67]} \mathrm{a}, 2015$ & & $0.23[-0.03,0.46]$ \\
\hline 周双珠等人 ${ }^{[2]} a, 2017$ & & $0.01[-0.36,0.37]$ \\
\hline 周双珠等人 ${ }^{[24]}$ b, 2017 & & $0.33[0.04,0.57]$ \\
\hline 周双珠等人 ${ }^{[24]} \mathrm{c}, 2017$ & & $0.36[0.09,0.58]$ \\
\hline 周双珠等人 ${ }^{[24]} \mathrm{d}, 2017$ & r & $-0.05[-0.32,0.23]$ \\
\hline 安连超等人 ${ }^{[68]}, 2018$ & F터 & $0.36[0.31,0.41]$ \\
\hline 田俊美等人 ${ }^{[69]}, 2018$ & & $0.31[0.00,0.57]$ \\
\hline 尚思源 ${ }^{[70]} a, 2018$ & $\mapsto-1$ & $0.30[0.22,0.38]$ \\
\hline 尚思源 ${ }^{[70]}$ b, 2018 & $\mapsto-1$ & $0.39[0.28,0.49]$ \\
\hline Barón等人 ${ }^{[22]}, 2018$ & $1-1$ & $0.46[0.37,0.54]$ \\
\hline Fang等人 ${ }^{[71]}, 2019$ & $1=-1$ & $0.48[0.41,0.55]$ \\
\hline RE模型 & & $0.27[0.21,0.33]$ \\
\hline & $\begin{array}{c}-0.40-0.200 .000 .200 .400 .60 \\
\text { 相关系数 }\end{array}$ & 0.80 \\
\hline
\end{tabular}

图 1 道德认知(a)、道德情绪(b)与亲社会行为关系的元分析森林图

Figure 1 Forest plots of associations of moral cognition (a) and moral emotion (b) with prosocial behavior

表 1 道德能力与亲社会行为关系的调节变量分析 ${ }^{a}$

Table 1 Summary of meta-analytic results on the effects of moderators on moral cognition and moral emotion

\begin{tabular}{|c|c|c|c|c|c|c|c|c|}
\hline \multirow{2}{*}{ 调节变量条件 } & \multicolumn{4}{|c|}{ 道德认知 } & \multicolumn{4}{|c|}{ 道德情绪 } \\
\hline & $k$ & $r$ & $95 \% C I$ & $Q_{\text {within }}$ & $k$ & $r$ & $95 \% C I$ & $Q_{\text {within }}$ \\
\hline 整体 & 39 & $0.22^{* * *}$ & $0.18,0.27$ & $160.05^{* * *}$ & 29 & $0.27^{* * *}$ & $0.21,0.33$ & $131.84^{* * *}$ \\
\hline 被试年龄 & & & & 5.86 & & & & 3.70 \\
\hline 学前儿童 & 3 & $0.24^{*}$ & $0.02,0.45$ & & 10 & $0.24^{* *}$ & $0.12,0.35$ & \\
\hline 学龄儿童 & 10 & $0.21^{* * *}$ & $0.11,0.30$ & & 7 & $0.21^{*}$ & $0.08,0.35$ & \\
\hline 青少年 & 18 & $0.19^{* * *}$ & $0.13,0.26$ & & 5 & $0.33^{* * *}$ & $0.18,0.47$ & \\
\hline 成人 & 8 & $0.33^{* * *}$ & $0.22,0.43$ & & 7 & $0.36^{* * *}$ & $0.23,0.49$ & \\
\hline 是否发表 & & & & 0.90 & & & & 0.22 \\
\hline 已发表 & 33 & $0.21^{* * *}$ & $0.16,0.27$ & & 25 & $0.27^{* * *}$ & $0.20,0.35$ & \\
\hline 未发表 & 6 & $0.27^{* * *}$ & $0.16,0.39$ & & 4 & $0.31^{* * *}$ & $0.15,0.47$ & \\
\hline
\end{tabular}

a) *, $P<0.050 ; * *, P<0.010 ; * * *, P<0.001$ 


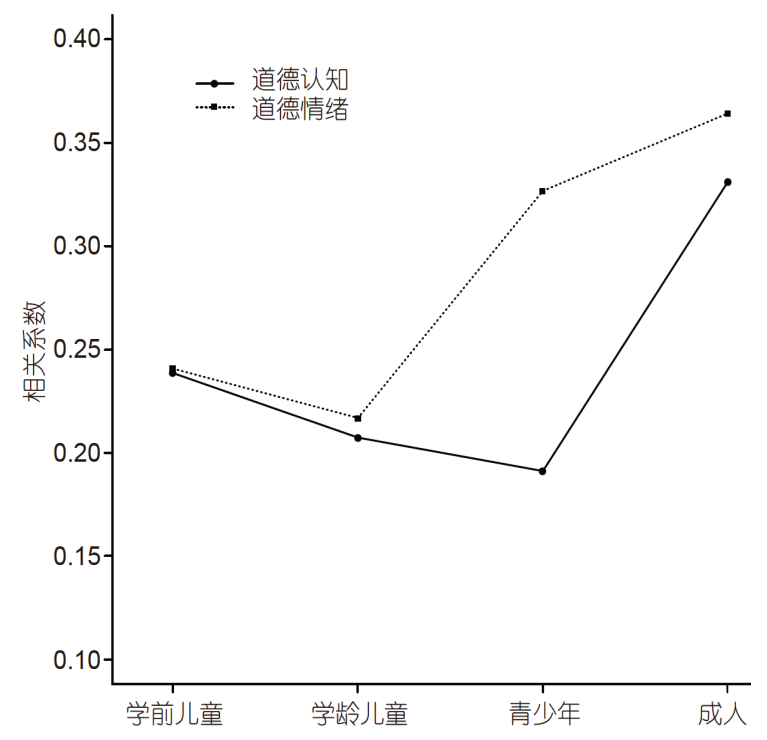

图 2 各年龄组中道德认知、道德情绪与亲社会行为关系比较

Figure 2 Comparation of associations of moral cognition and moral emotion with prosocial behavior in each age group

为关系的调节作用. 在这两个元分析的基础上, 进一步 比较了道德认知和道德情绪二者与亲社会行为关系及 其在各个年龄段中的发展变化，结果仅在青少年阶段 发现，二者与亲社会行为的相关程度存在边缘显著差 异, 其中道德情绪与亲社会行为的关系更为密切.

首先, 本元分析结果发现, 道德认知和道德情绪均 与亲社会行为存在中等程度的相关, 这与以往的研究

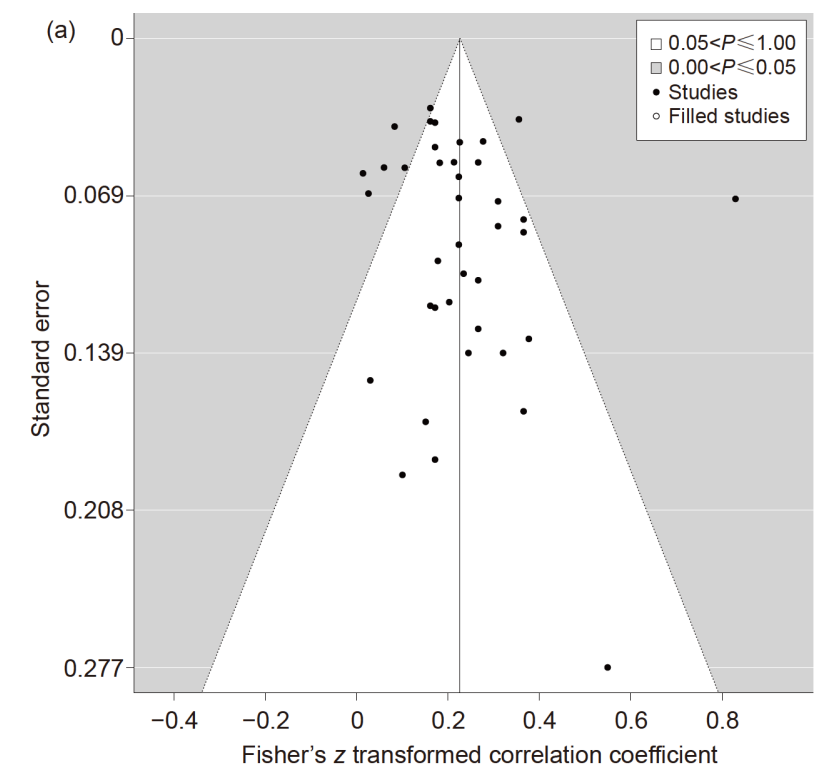

结果基本一致. 在吴鹏和刘华山 ${ }^{[29]}$ 针对道德认知与道 德行为关系的元分析研究中, 发现道德推理与亲社会 行为的相关系数为 $r=0.23$; Malti和Krettenauer ${ }^{[20]}$ 针对道 德情绪与道德行为关系的元分析中, 则发现道德情绪 与亲社会行为的相关系数为 $r=0.13$. 本元分析综合分析 了以往的研究, 确认了道德认知和道德情绪均与亲社 会行为存在密切的关系.

其次, 本研究重点关注了年龄的调节作用, 但并未 发现不同年龄阶段道德能力与亲社会行为关系的显著 差异, 这与以往元分析的结果也是一致的 ${ }^{[20,29]}$. 道德能 力与亲社会行为关系跨年龄的稳定性提示我们，道德 能力可能在一定程度上反映了与亲社会行为相关的个 体差异 ${ }^{[20]}$; 而这一结果也得到了人格和生理基础研究 的支持 ${ }^{[9,13,72,73]}$.

值得注意的是, 在道德认知和道德情绪二者对亲 社会行为的作用比较方面, 本研究发现整体上二者的 影响程度基本相同. 尽管并未发现道德能力与亲社会 行为的关系随年龄显著的变化，但分年龄段的结果显 示, 在青少年阶段, 亲社会行为与道德情绪的关系更为 密切; 这一结果提示我们考虑到从学龄前到成年各阶 段的发展特点 ${ }^{[20,74]}$ ，在不同年龄段道德情绪与道德认 知对亲社会行为的影响可能存在一定的差异. 在学龄 前和学龄早期, 儿童对于复杂情绪的理解还存在一定 局限 ${ }^{[74]}$ ，对于道德情绪的理解也受到认知能力的限制，

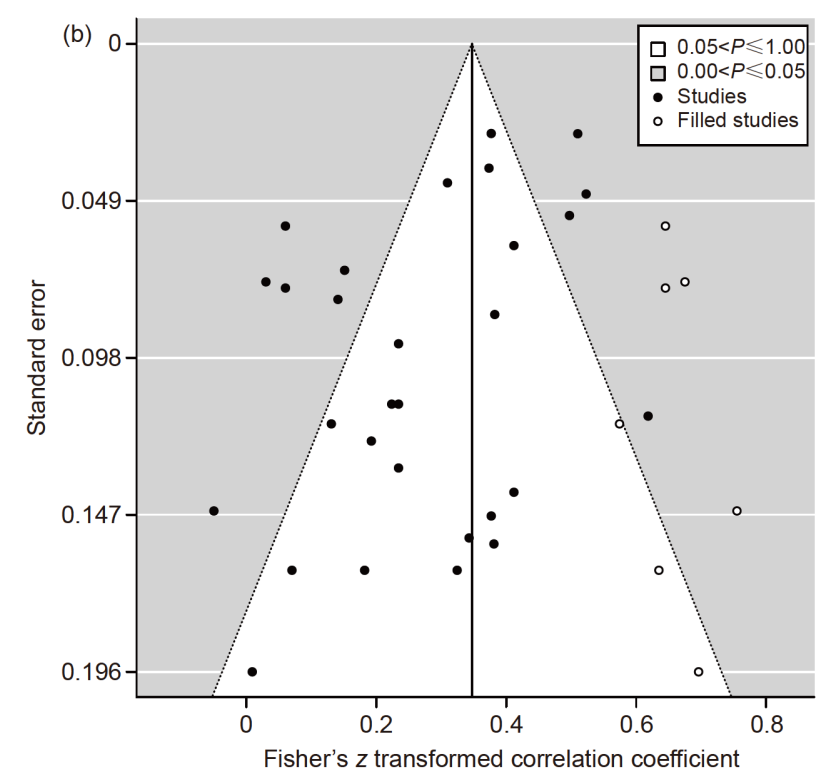

图 3 道德认知(a)、道德情绪(b)与亲社会行为关系的元分析漏斗图

Figure 3 Funnel plots of associations of moral cognition (a) and moral emotion (b) with prosocial behavior 
因而理解道德情绪的表现不能够充分体现他们对于道 德相关情绪的理解, 道德情绪对亲社会行为的影响也 没有凸显出来. 在以往考察学龄前和学龄儿童, 并同时 考察道德认知与道德情绪与亲社会行为关系的研究中, 既有发现道德认知独特作用的 ${ }^{[14,26]}$ ，也有发现道德情 绪独特影响的 ${ }^{[25]}$, 或二者同时发挥作用的 ${ }^{[21]}$. 可见, 在 这一阶段个体的道德认知和道德情绪对亲社会行为的 影响基本相当，而研究间的差异则可能受到这些研究 考察的亲社会行为类型等因素的影响.

随着年龄的增长, 到了青少年阶段, 个体已经获得 了理解道德情绪的相关的认知能力 ${ }^{[20]}$; 相比于道德认 知, 道德情绪与亲社会行为的关系更为密切. 尽管我们 没有发现直接比较青少年中道德认知和道德情绪对亲 社会行为作用异同的研究，但在探讨道德能力与反社 会行为关系的研究中, 均发现了道德情绪独特的作 用 ${ }^{[27,28]}$. 这提示我们，在对亲社会行为的影响上，道德 认知和道德情绪可能确实存在一定的差异, 而这种差 异在特定年龄阶段显现出来，特别是可能与青少年阶 段个体的发展特点息息相关. 青少年阶段个体激素水 平和大脑发育都处于发展进程中 ${ }^{[75]}$ ，其显著的特点之 一就是腹侧情感系统的成熟和过度激活 ${ }^{[76]}$. 其中, 青少 年阶段杏仁核的活动与儿童和成人存在差异，例如青 少年在面对负性情绪面孔时，杏仁核有更大的激活 ${ }^{[77]}$. 杏仁核的激活与道德情绪理解有关 ${ }^{[78]}$, 而与道德认知 无关 ${ }^{[79]}$. 可见，杏仁核活动的异常，可能使得青少年对 于道德情绪相关信息也存在较高的敏感性，进而影响 其社会行为. 此外，青少年受到同伴的影响尤为凸 显 $^{[80]}$, 同伴群体可能影响他们对于社会行为的履行 ${ }^{[81]}$, 这也可能在一定程度上干扰了道德认知对亲社会行为 的作用.

然而, 本研究还存在一定的局限性. 首先, 元分析 涉及的探讨道德能力与亲社会行为关系的研究中, 研 究者对于个体道德认知和道德情绪的测量, 其实并未 完全分离认知成分和情绪成分. 在道德认知能力的测 量中, 研究者主要使用经典的道德两难故事 ${ }^{[82,83]}$, 根据 道德两难故事和亲社会道德两难故事的内在逻辑自编 的道德故事情境 ${ }^{[12,28,84]}$, 以及确定问题测验和亲社会推 理客观测量等标准化测量工具 ${ }^{[11]}$ 对个体的道德认知发 展水平进行评价. 尽管研究者倾向于将这些判断和推 理过程归结为道德认知过程，但这些认知过程并非没 有情绪相关加工的参与. 同样的, 研究通常使用情境故 事任务, 考察被试对故事中的主人公或者自己处于相
应情境中时的情绪评价 ${ }^{[85,86]}$, 并对行为者做出道德相 关行为后的情绪进行解释和归因 ${ }^{[27]}$. 此外, 一些研究使 用启动的范式，让被试去描述或回忆自己的生活事件， 来激发其特定的道德情绪体验 ${ }^{[32]}$; 或使用特定道德情 绪的自我评价量表来探讨特定道德情绪与亲社会行为 的关系 ${ }^{[87]}$. 这些任务虽然更为强调道德能力中情绪相 关的成分, 但同样需要个体进行一定的认知推理. 因 此，尽管元分析的结果能够在一定程度上帮助我们理 解道德认知和道德情绪对亲社会行为的影响, 但想要 进一步厘清其中的认知和情绪成分, 仍需要更多的研 究从测量的角度出发对道德认知和道德情绪进行更系 统的区分.

其次，元分析中分属于各个年龄段的研究相对有 限, 受到研究数量的限制, 尤其在探讨年龄与道德认 知/情绪的交互作用时, 元分析的结果需要更加谨慎的 理解和解释. 尽管本研究中并未发现年龄与道德能力 的显著交互作用，但在各年龄组中道德认知、道德情 绪与亲社会行为关系比较图中(图3)可见，道德认知和 道德情绪在青少年阶段的影响有较大的分离, 而事后 检验也发现青少年阶段二者与亲社会行为的相关程度 存在边缘显著的差异. 因此, 想要更好地理解道德认知 和道德情绪对于亲社会行为的作用及其在不同年龄阶 段中的异同, 仍需要有更多的实证研究的支持.

最后, 同样受到研究数量的限制, 鲜有研究分别报 告或比较不同性别群体中的结果, 故而未能在本研究 中探讨性别差异的影响. 事实上, 被试的性别是影响其 道德能力和亲社会行为表现的重要影响因素. Gilli$\operatorname{gan}^{[18]}$ 认为, 男性和女性在道德发展的轨迹上可能存在 一定的差异, 其中男性更倾向于使用公正原则, 而女性 则更倾向于关爱他人，这一论点也得到了相关研究和 元分析的验证 ${ }^{[88]}$. 而在亲社会行为上研究者同样发现 了一定的性别差异 ${ }^{[89,90]}$. 这些研究结果提示, 被试的性 别可能是影响道德能力与亲社会行为关系的一个影响 因素 ${ }^{[30]}$, 故而需要在今后的研究中加以探讨.

\section{4 结论}

本元分析发现, 道德认知和道德情绪均与亲社会 行为有关, 道德认知能力较高的个体和道德情绪理解 能力较好的个体, 均有更加亲社会的行为表现. 在青少 年阶段, 道德认知和道德情绪二者对亲社会行为的影 响存在差异，道德情绪与亲社会行为的联系比道德认 知更为密切. 


\section{参考文献}

1 Koenig A L, Cicchetti D, Rogosch F A. Moral development: The association between maltreatment and young children's prosocial behaviors and moral transgressions. Soc Dev, 2004, 13: 87-106

2 Luo G J. Encyclopedia of Chinese Ethics: Principles of Ethics (Vol. 1) (in Chinese). Jilin: Jilin People’s Publishing House, 1993 [罗国杰. 中国伦 理学百科全书: 伦理学原理卷(卷一). 吉林: 吉林人民出版社, 1993]

3 Zhu Y T. A Dictionary of Ethics (in Chinese). Shanghai: Shanghai Dictionary Publishing House, 2002 [朱贻庭. 伦理学大辞典. 上海: 上海辞书出 版社, 2002]

4 Shaffer D R. Do "naturalistic" conceptions of morality provide any novel answers? J Pers, 1994, 62: 263-268

5 Nunner-Winkler G. Development of moral motivation from childhood to early adulthood. J Moral Educ, 2007, 36: 399-414

6 Verbeek P. Everyone's monkey: Primate moral roots. In: Killen M, Smetana J G, eds. Handbook of Moral Development. New York and London: Psychology Press, 2005. 423-475

7 Carlo G, Randall B A. The development of a measure of prosocial behaviors for late adolescents. J Youth Adolesc, 2002, 31: 31-44

8 Israel S, Hasenfratz L, Knafo-Noam A. The genetics of morality and prosociality. Curr Opin Psychol, 2015, 6: 55-59

9 Christ C C, Carlo G, Stoltenberg S F. Oxytocin receptor (OXTR) single nucleotide polymorphisms indirectly predict prosocial behavior through perspective taking and empathic concern. J Pers, 2016, 84: 204-213

10 Rubin K H, Schneider F W. The relationship between moral judgment, egocentrism, and altruistic behavior. Child Dev, 1973, 44: 661-665

11 Eisenberg N, Cameron E, Pasternack J, et al. Behavioral and sociocognitive correlates of ratings of prosocial behavior and sociometric status. J Genet Psychol, 1988, 149: 5-15

12 Eisenberg N, Shell R. Prosocial moral judgment and behavior in children. Pers Soc Psychol Bull, 1986, 12: 426-433

13 Eriksson O, Lalowski M, Lindholm D. Commentary: LACTB is a tumour suppressor that modulates lipid metabolism and cell state. Front Physiol, 2017, 8: 396

14 Malti T, Gasser L, Gutzwiller-Helfenfinger E. Children's interpretive understanding, moral judgments, and emotion attributions: Relations to social behaviour. Br J Psychol Soc, 2010, 28: 275-292

15 Mao J S. Research on the relationship among moral judgment ability, guilt and pro-social behaviors of middle school students (in Chinese). Master Thesis. Chengdu: Sichuan Normal University, 2012 [毛静思. 中学生道德判断能力、内疚与亲社会行为的关系研究. 硕士学位论文. 成都: 四 川师范大学, 2012]

16 Eisenberg N. Emotion, regulation, and moral development. Annu Rev Psychol, 2000, 51: 665-697

17 Cen G Z. From justice to care and forgiveness: A brief discussion of three themes on moral psychology (in Chinese). Chin Psychol Sci, 1998, 21: 163-166 [岑国桢. 从公正到关爱、宽恕——道德心理研究三主题略述. 心理科学, 1998, 21: 163-166]

18 Gilligan C. In a different voice: Women's conceptions of self and of morality. Harv Educ Rev, 1977, 47: 481-517

19 Nunner-Winkler G, Sodian B. Children's understanding of moral emotions. Child Dev, 1988, 59: 1323-1328

20 Malti T, Krettenauer T. The relation of moral emotion attributions to prosocial and antisocial behavior: A meta-analysis. Child Dev, 2013, 84: 397412

21 Miller P A, Eisenberg N, Fabes R A, et al. Relations of moral reasoning and vicarious emotion to young children's prosocial behavior toward peers and adults. Dev Psychol, 1996, 32: 210-219

22 Barón J O, Bilbao I E, Urquijo P A, et al. Moral emotions associated with prosocial and antisocial behavior in school-aged children. Psicothema, 2018, 30: $82-88$

23 Malti T, Gummerum M, Keller M, et al. Children's moral motivation, sympathy, and prosocial behavior. Child Dev, 2009, 80: 442-460

24 Zhou S Z, Chen Y H, Hu Z J, et al. Children's emotion understanding in moral and personal domain and its influence to their prosocial behavior (in Chinese). Chin Psychol Explor, 2017, 37: 41-47 [周双珠, 陈英和, 胡竹菁, 等. 道德和个人领域儿童情绪理解的发展特点及对其亲社会行为 的影响. 心理学探新, 2017, 37: 41-47]

25 Gummerum M, Hanoch Y, Keller M, et al. Preschoolers' allocations in the dictator game: The role of moral emotions. J Econ Psychol, 2010, 31: $25-34$

26 Ongley S F, Nola M, Malti T. Children's giving: Moral reasoning and moral emotions in the development of donation behaviors. Front Psychol, 2014, 5: 458

27 Arsenio W F, Adams E, Gold J. Social information processing, moral reasoning, and emotion attributions: Relations with adolescents' reactive and proactive aggression. Child Dev, 2010, 80: 1739-1755

28 Krettenauer T, Eichler D. Adolescents' self-attributed moral emotions following a moral transgression: Relations with delinquency, confidence in moral judgment and age. Br J Dev Psychol, 2006, 24: 489-506 
29 Wu P, Liu H S. Association between moral reasoning and moral behavior: A systematic review and meta-analysis (in Chinese). Acta Psychol Sin, 2014, 46: 1192-1207 [吴鹏, 刘华山. 道德推理与道德行为关系的元分析. 心理学报, 2014, 46: 1192-1207]

30 Carlo G, Mestre M V, Samper P, et al. Feelings or cognitions? Moral cognitions and emotions as longitudinal predictors of prosocial and aggressive behaviors. Pers Individ Differ, 2010, 48: 872-877

31 Hong L. A study on the relationship among altruistic behavior, empathy and moral judgment of senior middle school students (in Chinese). Master Thesis. Fuzhou: Fujian Normal University, 2005 [洪丽. 高中生利他行为与移情、道德判断关系研究. 硕士学位论文. 福州: 福建师范大学, 2005]

32 de Hooge I E, Nelissen R M A, Breugelmans S M, et al. What is moral about guilt? Acting "prosocially" at the disadvantage of others. J Pers Soc Psychol, 2011, 100: 462-473

33 Ellis P D. Effect size calculators. 2009, http://www.polyu.edu.hk/mm/effectsizefaqs/calculator/calculator.html

34 Viechtbauer W. Conducting meta-analyses in R with the metafor package. J Stat Softw, 2010, 36: 1-48

35 Borenstein M, Hedges L V, Higgins J P T, et al. A basic introduction to fixed-effect and random-effects models for meta-analysis. Res Synth Method, 2010, 1: 97-111

36 Eisenberg N, Carlo G, Murphy B, et al. Prosocial development in late adolescence: A longitudinal study. Child Dev, 1995, 66: 1179-1197

37 Hart D, Fegley S. Prosocial behavior and caring in adolescence: Relations to self-understanding and social judgment. Child Dev, 1995, 66: 13461359

38 Carlo G, Koller S H, Eisenberg N, et al. A cross-national study on the relations among prosocial moral reasoning, gender role orientations, and prosocial behaviors. Dev Psychol, 1996, 32: 231-240

39 Janssens J M A M, Deković M. Child rearing, prosocial moral reasoning, and prosocial behaviour. Int J Behaval Dev, 1997, 20: 509-527

40 Wagner S L, Rush M C. Altruistic organizational citizenship behavior: Context, disposition, and age. J Soc Psychol, 2000, 140: 379-391

41 Liu Z J. Study on the relationship between peer relationship and prosocial behavior of middle school students' level of moral judgment and reasoning (in Chinese). Chin Psychol Sci, 2001, 24: 629-630 [刘志军. 中学生的道德判断推理水平, 同伴关系和亲社会行为关系的研究. 心理 科学, 2001, 24: 629-630]

42 Eisenberg N, Zhou Q, Koller S. Brazilian adolescents' prosocial moral judgment and behavior: Relations to sympathy, perspective taking, genderrole orientation, and demographic characteristics. Child Dev, 2001, 72: 518-534

43 Shumaker D M. Altruism, empathy, and moral reasoning in high-risk children. Doctoral Dissertation. Columbia: University of South Carolina, 2002

44 Brugman D, Heymans P G, Boom J, et al. Perception of moral atmosphere in school and norm transgressive behaviour in adolescents: An intervention study. Int J Behaval Dev, 2003, 27: 289-300

45 Ma H K. The relation of moral orientation and moral judgment to prosocial and antisocial behaviour of Chinese adolescents. Int J Psychol, 2003, 38: 101-111

46 Maclean A M, Walker L J, Matsuba M K. Transcendence and the moral self: Identity integration, religion, and moral life. J Sci Stud Relig, 2004, 43: 429-437

47 Zhu D, Li D. Moral reasoning, empathetic response, and prosocial behavior: Their interrelations in middle school (in Chinese). Chin Psychol Sci, 2005, 28: 1231-1234 [朱丹, 李丹. 初中学生道德推理、移情反应、亲社会行为及其相互关系的比较研究. 心理科学, 2005, 28: 1231-1234]

48 Hardy S A, Kisling J W. Identity statuses and prosocial behaviors in young adulthood: A brief report. Identity, 2006, 6: 363-369

49 Carlo G, Mestre M V, Samper P, et al. The longitudinal relations among dimensions of parenting styles, sympathy, prosocial moral reasoning, and prosocial behaviors. Int J Behav Dev, 2010, 48: 116-124

50 Iroh A. Moral action decision process: Using multiple constructs to predict adolescents' moral action choices. Doctoral Dissertation. New York: Fordham University, 2010

51 Beechler M P. A bioecological approach to empathy, altruism, and intent to help: Developmental, dispositional and contextual factors influence prosocial motivations and intentions. Doctoral Dissertation. Michigan: Wayne State University, 2011

52 Rutten E A, Schuengel C, Dirks E, et al. Predictors of antisocial and prosocial behavior in an adolescent sports context. Social Dev, 2011, 20: 294315

53 Li W. Research on the applicability of the internet altruistic behavior scale and the relationship between moral judgment and internet altruistic behavior of post graduates (in Chinese). Master Thesis. Shanghai: East China Normal University, 2012 [李炜. 硕士研究生网络利他行为的量表 适用性及其与道德判断间关系. 硕士学位论文. 上海: 华东师范大学, 2012]

54 Knight G P, Carlo G, Basilio C D, et al. Familism values, perspective taking, and prosocial moral reasoning: Predicting prosocial tendencies among Mexican American adolescents. J Res Adolesc, 2015, 25: 717-727

55 Shang S, Wu N, Su Y. How oxytocin receptor (OXTR) single nucleotide polymorphisms act on prosociality: The mediation role of moral evaluation. Front Psychol, 2017, 8: 396 
56 Patrick R B, Bodine A J, Gibbs J C, et al. What accounts for prosocial behavior? Roles of moral identity, moral judgment, and self-efficacy beliefs. J Genet Psychol, 2018, 179: 231-245

57 Shields D L, Funk C D, Bredemeier B L. Relationships among moral and contesting variables and prosocial and antisocial behavior in sport. J Moral Educ, 2018, 47: 17-33

58 Belacchi C, Farina E. Utilitarian and emotion-related components of moral judgement: Gender and age effects and the relationship with prosocial and hostile roles in bullying. Eur J Dev Psychol, 2018, 15: 1-14

59 Li J, Hao J, Shi B. From moral judgments to prosocial behavior: Multiple pathways in adolescents and different pathways in boys and girls. Pers Individ Differ, 2018, 134: 149-154

60 Ding W, Shao Y, Sun B, et al. How can prosocial behavior be motivated? The different roles of moral judgment, moral elevation, and moral identity among the young Chinese. Front Psychol, 2018, 9: 814

61 Garner P W. The relations of emotional role taking, affective/moral attributions, and emotional display rule knowledge to low-income school-age children's social competence. J Appl Dev Psychol, 1996, 17: 19-36

62 DeHaan R, Hanford R, Kinlaw K, et al. Promoting ethical reasonings affect and behaviour among high school students: An evaluation of three teaching strategies. J Moral Educ, 1997, 26: 5-20

63 Malti T, Gummerum M, Buchmann M. Contemporaneous and 1-year longitudinal prediction of children's prosocial behavior from sympathy and moral motivation. J Genet Psychol, 2007, 168: 277-299

64 Johnston M E. Moral emotion expectancies and moral behavior in adolescence. Doctoral Dissertation. Ontario: Wilfrid Laurier University, 2009

65 O’Mara E M, Jackson L E, Batson C D, et al. Will moral outrage stand up?: Distinguishing among emotional reactions to a moral violation. Eur J Soc Psychol, 2011, 41: 173-179

66 Van de Vyver J, Abrams D. Testing the prosocial effectiveness of the prototypical moral emotions: Elevation increases benevolent behaviors and outrage increases justice behaviors. J Exp Soc Psychol, 2015, 58: 23-33

67 Ketelaar L, Wiefferink C H, Frijns J H M, et al. Preliminary findings on associations between moral emotions and social behavior in young children with normal hearing and with cochlear implants. Eur Child Adolesc Psychiatr, 2015, 24: 1369-1380

68 An L C, Zhang S C, Wang H, et al. The influence of empathy on college students' prosocial behavior: The multiple mediating effect of moral disengagement and guilt (in Chinese). Chin Psychol Explor, 2018, 38: 350-355 [安连超, 张守臣, 王宏, 等. 共情对大学生亲社会行为的影响: 道 德推脱和内疚的多重中介作用. 心理学探新, 2018, 38: 350-355]

69 Tian J M, Liu D D, Lu F R. The effect of moral emotion on the prosocial behavior of college students (in Chinese). Chin Psychol Tech Appl, 2018, 6: 714-721 [田俊美, 刘丹丹, 卢富荣. 道德情绪对大学生亲社会行为的影响. 心理技术与应用, 2018, 6: 714-721]

70 Shang S Y. From moral understanding to prosocial behavior: Gender and situational differences (in Chinese). Doctor Thesis. Beijing: Peking University, 2018 [尚思源. 从道德理解到亲社会行为: 性别差异及情境因素的影响. 博士学位论文. 北京: 北京大学, 2018]

71 Fang Y, Dong Y, Fang L. Honesty-humility and prosocial behavior: The mediating roles of perspective taking and guilt-proneness. Scand J Psychol, 2019, 60: 386-393

72 Krettenauer T, Asendorpf J B, Nunner-Winkler G. Moral emotion attributions and personality traits as long-term predictors of antisocial conduct in early adulthood. Int J Behaval Dev, 2013, 37: 192-201

73 Walter N T, Montag C, Markett S, et al. Ignorance is no excuse: Moral judgments are influenced by a genetic variation on the oxytocin receptor gene. Brain Cogn, 2012, 78: 268-273

74 Krettenauer T, Malti T, Sokol B W. The development of moral emotion expectancies and the happy victimizer phenomenon: A critical review of theory and application. Int J Dev Sci, 2008, 2: 221-235

75 De Bolle M, De Fruyt F, McCrae R R, et al. The emergence of sex differences in personality traits in early adolescence: A cross-sectional, crosscultural study. J Pers Soc Psychol, 2015, 108: 171-185

76 Do K T, Moreira J F G, Telzer E H. But is helping you worth the risk? Defining prosocial risk taking in adolescence. Dev Cogn Neurosci, 2017, 25: 260-271

77 Guyer A E, Monk C S, McClure-Tone E B, et al. A developmental examination of amygdala response to facial expressions. J Cogn Neurosci, 2008, 20: $1565-1582$

78 Moll J, de Oliveira-Souza R, Bramati I E, et al. Functional networks in emotional moral and nonmoral social judgments. NeuroImage, 2002, 16: 696-703

79 Moll J, de Oliveira-Souza R, Eslinger P J, et al. The neural correlates of moral sensitivity: A functional magnetic resonance imaging investigation of basic and moral emotions. J Neurosci, 2002, 22: 2730-2736

80 Hart D, Carlo G. Moral development in adolescence. J Res Adolesc, 2010, 15: 223-233

81 Svensson R, Pauwels L J R, Weerman F M, et al. Explaining individual changes in moral values and moral emotions among adolescent boys and girls: A fixed-effects analysis. Eur J Criminol, 2017, 14: 290-308 
82 Cushman F, Young L, Hauser M. The role of conscious reasoning and intuition in moral judgment. Psychol Sci, 2006, 17: 1082-1089

83 Greene J D, Cushman F A, Stewart L E, et al. Pushing moral buttons: The interaction between personal force and intention in moral judgment. Cognition, 2009, 111: 364-371

84 Wang P, Liu H Y, Fang P. Research on features of adolescents' judgments and attributions of moral emotion (in Chinese). Chin Psychol Explor, 2011, 31: 182-185 [王鹏, 刘海燕, 方平. 青少年道德情绪判断与归因特点研究. 心理学探新, 2011, 31: 182-185]

85 Malti T, Gasser L, Buchmann M. Aggressive and prosocial children's emotion attributions and moral reasoning. Aggr Behav, 2009, 35: 90-102

86 Hawley P H, Geldhof G J. Preschoolers' social dominance, moral cognition, and moral behavior: An evolutionary perspective. J Exp Child Psychol, 2012, 112: 18-35

87 Kavussanu M, Ring C. Moral identity predicts doping likelihood via moral disengagement and anticipated guilt. J Sport Exerc Psychol, 2017, 39: 293-301

88 Jaffee S, Hyde J S. Gender differences in moral orientation: A meta-analysis. Psychol Bull, 2000, 126: 703-726

89 Toseeb U, Pickles A, Durkin K, et al. Prosociality from early adolescence to young adulthood: A longitudinal study of individuals with a history of language impairment. Res Dev Disabil, 2017, 62: 148-159

90 Zhang M Y, Yang Y, Kou Y. The adolescents' prosocial behavior and its development (in Chinese). Chin Youth Stud, 2015, (4): 10-18 [张梦圆, 杨 莹, 寇或. 青少年的亲社会行为及其发展. 青年研究, 2015, (4): 10-18]

\section{补充材料}

图S1 文献筛选流程

表S1 元分析文献编码

本文以上补充材料见网络版csb.scichina.com. 补充材料为作者提供的原始数据, 作者对其学术质量和内容负责. 


\title{
Association between moral cognition, moral emotion and prosocial behavior: Evidence from meta-analysis
}

\author{
Siyuan Shang ${ }^{1,2} \&$ Yanjie $\mathrm{Su}^{2 *}$ \\ ${ }^{1}$ Zhejiang Key Laboratory for Research in Assessment of Cognitive Impairments, Institutes of Psychological Sciences, Hangzhou Normal University, \\ Hangzhou 311121, China; \\ ${ }^{2}$ Beijing Key Laboratory of Behavior and Mental Health, School of Psychological and Cognitive Sciences, Peking University, Beijing 100871, China \\ * Corresponding author, E-mail: yjsu@pku.edu.cn
}

Moral competence plays an important role in social, family, and peer relationships, and thus has received extensive attention. A large number of studies on children and adults have found that the cognitive and emotional components of moral competence can have a certain degree of impact on social interaction and social behaviors. Among these outcomes, prosocial behavior, or "behaviors aimed at benefiting others", is considered important in moral development. Yet, relationship between moral cognition, moral emotion and prosocial behavior still needs to be further clarified. Especially, the large body of research on prosocial behavior has provided only limited direct comparison as to how the influences from moral cognition and moral emotion are similar and different. Therefore, the current meta-analysis was conducted to compare the roles of moral cognition and moral emotion in prosocial behavior. In addition, because maturation of moral cognition and moral emotion with age might moderate their relationship with prosocial behavior, age of participant was included as a potential moderator of interest.

Empirical studies with typically developing participants at or over the age 3 years were selected. Then, results were systematically pooled to show how the roles of moral cognition and moral emotion might differ. Effect sizes describing the relationship between moral competence and prosocial behavior were extracted/calculated from the data.

Altogether, 39 independent effect sizes (9960 participants) for moral cognition and 29 independent effect sizes (6946 participants) for moral emotion were retained for meta-analysis. All data were analyzed in R (3.6.1) with the Metafor package.

The results showed that both moral cognition $(r=0.22)$ and moral emotion $(r=0.27)$ were positively associated with prosocial behavior. There were significant differences across studies in the strength of the relationship between moral competence and prosocial behavior, but the current meta-analysis did not yield evidence of statistical difference that age could explain these differences.

Further analysis revealed that moral emotion and moral cognition played the same role overall. In most age groups, the two predictors had similar effect sizes on prosocial behavior, and only in adolescents, moral emotion had a stronger association with prosocial behavior at marginal significance than moral cognition had. One explanation is that individual hormone levels and brain structures are developing rapidly in adolescence, which may make adolescents more sensitive to information conveyed by moral emotion than that by moral cognition and greatly strengthen the influences of moral emotion on their social behaviors. Further studies are desired to examine the finer differences between the roles of moral emotion and moral cognition in relation to the developmental characteristics at different stages from preschool to adulthood.

Overall, the findings provided evidence that both moral cognition and moral emotion were associated with prosocial behavior, and played similar roles despite a trend toward difference at certain development stages.

moral cognition, moral emotion, prosocial behavior, meta-analysis

doi: 10.1360/TB-2019-0676 